\section{Colorimetric method for estimating methylmalonic acid in urine}

\author{
ALAN GREEN From the Department of \\ Haematology, Charing Cross Hospital Medical \\ School, London
}

The increased urinary excretion of methylmalonic acid in vitamin $\mathbf{B}_{\mathbf{1 2}}$ deficiency has attracted attention and several studies have suggested that it has clinical value as a test of vitamin $B_{12}$ deficiency (Cox and White, 1962; Bashir, Hinterberger, and Jones, 1966).

Chromatographic methods of estimation have been used but are either time consuming or only semiquantitative over a narrow range of methylmalonic acid levels. Giorgio and Plaut (1965) described a quantitative colorimetric method using the coupling of methylmalonic acid with diazotised p-nitroaniline after purification of urine by ion exchange resin. The resin they used (Dowex 3) is no longer available.

As the rapid detection of methylmalonic aciduria has potential use in the clinical laboratory in patients in whom multiple haematinic deficiencies may be present, it was decided to try to develop a suitable method using this colour reaction.

\section{PRINCIPLE}

Acidified urine is saturated with ammonium sulphate and extracted with ethanol/ether. The extract is passed through a strongly basic ion exchange resin column. Methylmalonic acid is eluted with hydrochloric acid and coupling with diazotised p-nitroaniline is carried out on an aliquot of the effluent.

\section{MATERIALS}

Urine is collected for 24 hours after $10 \mathrm{~g}$ of valine has been administered orally (Gompertz, Jones, and Knowles, 1967); $10 \mathrm{ml}$ of concentrated hydrochloric acid may be used as a preservative.

Diethyl ether AR and ethanol AR

0.1N HCl Ammonium sulphate (GPR)

Deacidite FF (IP) < 200 mesh, chloride form. (Permutit Co. Ltd.).

DIAZO REAGENT requires aqueous sodium nitrite, $0.5 \%$ (W/V), p-nitroaniline, $750 \mathrm{mg}$ per litre in $0.2 \mathrm{~N} \mathrm{HCl}$, and aqueous sodium acetate, $0.2 \mathrm{M}$.

Sodium nitrite solution, $4 \mathrm{ml}$, and $15 \mathrm{ml} \mathrm{p}$-nitroaniline solution are mixed and cooled in an ice bath and $4 \mathrm{ml}$ sodium acetate solution is added.

Molar acetate buffer pH 4.3 is prepared from sodium acetate AR solution and acetic acid AR mixed in the ratio $16.35: 33.90$.

$3 \mathrm{~N}$ sodium hydroxide aqueous.
STOCK STANDARD METHYLMALONIC ACID Methylmalonic acid (Kodak Ltd., Kirkby, Liverpool), $100 \mathrm{mg}$, is dissolved in $100 \mathrm{ml}$ of water and stored in the refrigerator.

DILUTE STANDARD METHYLMALONIC ACID Stock methylmalonic acid standard solution, $1 \mathrm{ml}$, is made to $20 \mathrm{ml}$ with $0 \cdot 1 \mathrm{~N} \mathrm{HCl}$. This solution is equivalent to $100 \mathrm{mg}$ methylmalonic acid per litre of urine under the conditions of the test

\section{METHOD}

PURIFICATION OF URINE The 24-hour urine volume is measured and $10 \mathrm{ml}$ is acidified to $\mathrm{pH} 2$ or less using $\mathrm{N}$ sulphuric acid (testing with narrow range indicator paper) saturated with ammonium sulphate and extracted three times with $15 \mathrm{ml}$ ether/ethanol $(3: 1)$ in a separating funnel. Emulsions can be avoided by maintaining the excess of extractant. The small quantity of ammonium sulphate thrown out of solution can be ignored.

The combined extracts are passed through a $5 \mathrm{~cm}$ long column of resin prepared wet in a 1 to $1.5 \mathrm{~cm}$ diameter column. Very light suction may be used and a resin column may be expected to shrink by about a centimetre. The column is washed with $50 \mathrm{ml}$ distilled water, again with light suction. HC1.

The methylmalonic acid is eluted with $20 \mathrm{ml}$ of $0 \cdot 1 \mathrm{~N}$

DEVELOPMENT OF COLOUR After thorough mixing, $2 \mathrm{ml}$ of the effluent is taken, $3 \mathrm{ml}$ acetate buffer added followed by $3 \mathrm{ml}$ diazo reagent, and, after mixing, the tube is heated in a water bath at $95^{\circ} \mathrm{C}$ for three minutes. After removing from the bath $2 \mathrm{ml} 3 \mathrm{~N} \mathrm{NaOH}$ is added, the tube mixed gently and stoppered immediately. It is essential to keep contact with air to a minimum. After cooling, the optical density is read in $1 \mathrm{~cm}$ cells at $620 \mathrm{~m} \mu$.

A 'reagent blank' is set up using $2 \mathrm{ml} 0 \cdot 1 \mathrm{~N} \mathrm{HC1}$ instead of the eluate and, also a standard containing $2 \mathrm{ml}$ of the dilute methylmalonic acid standard solution instead of eluate.

For occasional assays a urine of known methylmalonic acid content should be taken through the whole procedure.

\section{COMMENT}

STABILITY OF METHYLMALONIC ACID IN URINE Methylmalonic acid added to urine collected in the way described has been found to be unaffected by storage at $-20^{\circ} \mathrm{C}$ for at least four months. The concentrated hydrochloric acid has been found necessary when dealing with the infected urine often collected from geriatric patients.

PURIFICATION OF EXTRACT Though ether/ethanol extraction yields a better recovery than extraction with ether alone, to minimize interfering colours passage through an ion exchange resin column was found necessary. The extract can be applied directly to the resin column without causing functional disturbance of the bed. 
THE COLOUR REACTION Optimal conditions for the development of the colour are discussed by Giorgio and Plaut (1965) and have been confirmed. Values above $150 \mathrm{mg}$ per litre may be estimated by dilution of a further aliquot of the eluate. Because of the variation of $\mathrm{E}^{620}$ due to interfering brown pigments, values below $15 \mathrm{mg} /$ litre are not reported but the levels found in vitamin $B_{12}$ deficiency have been reported to be above $50 \mathrm{mg}$ after valine loading, and this was so in nine patients with pernicious anaemia whose urine has been tested using this method.

RECOVERIES Recovery of methylmalonic acid from aqueous solutions and from additions to various urine samples by this method is $70-80 \%$ (Table), almost all the loss being in the ether/ethanol extraction stage. Recovery may be improved by increasing the number of extractions. Purity of the extract has been confirmed by thin-layer chromatography.

\section{TABLE}

RECOVERIES OF METHYLMALONIC ACID ADDED TO URINE

\begin{tabular}{ccrc}
$\begin{array}{l}\text { No. of } \\
\text { Estimations }\end{array}$ & $\begin{array}{l}\text { Methylmalonic } \\
\text { Acids Added } \\
(\mathrm{mg})\end{array}$ & $\begin{array}{l}\text { Methylmalonic } \\
\text { Acid Found } \\
\text { Mean } \pm 2 S D \\
(\mathrm{mg})\end{array}$ & $\begin{array}{l}\text { Mean } \\
\text { Percentage } \\
\text { Recovery }\end{array}$ \\
\hline 3 & 250 & $180 \pm 15$ & 72 \\
3 & 175 & $130 \pm 10$ & 74 \\
12 & 100 & $79 \pm 9$ & 79
\end{tabular}

SUMMARY

A colorimetric method for the estimation of methylmalonic acid in urine is described. The method is suitable for use in clinical pathology laboratories.

Acidified urine is saturated with ammonium sulphate and extracted with ethanol and ether, and the extract is purified using a strongly basic ion exchange resin. The methylmalonic acid is eluted and a colour developed by coupling with diazotised p-nitroaniline.

I should like to thank Dr. J. S. Swale for much valuable discussion, Dr. Kressman of Permutit Co. Ltd. for samples of various ion exchange resins, and The Dow Chemical Co. for resin samples.

\section{REFERENCES}

Bashir, H. V., Hinterberger, H., and Jones, B. P. (1966) .Brit, J. Haemat., 12, 704.

Cox, E. V., and White, A. M. (1962). Lancet, 2, 853.

Giorgio, A. J., and Plaut, G. W. E. (1965). J. Lab. clin. Med., 6b, 667 Gompertz, D., Jones, J. H., and Knowles, J. P. (1967). Lancet, 1, 424.

\section{Measurement of mean corpuscular and packed cell volumes with a Coulter cell counter}

A. CARTER, P. J. CROSLAND-TAYLOR, AND J. W. STEWART From the Bland-Sutton Institute, Middlesex Hospital, London

The demonstration by Mattern, Brackett, and Olson (1957) that the Coulter cell counter could be used for cell sizing has been confirmed by many others (Douglas and Atkinson, 1960; Grant, Britton, and Kurtz, 1960; Brecher, Jakobek, Schneiderman, Williams, and Schmidt, 1962; Nevius, 1963; Lushbaugh and Lushbaugh, 1965).

A small computer is now available from Coulter Electronics Ltd., Dunstable, Bedfordshire, England, which can be attached to Coulter cell counter models B and F. This summates the size of the pulses produced by the cells over a period during the actual count, divides by the number of cells, including correction for coincidence, and displays the mean corpuscular volume (MCV). An additional computer, used in conjunction with the above, will calculate the packed cell volume (PCV) from the MCV and the total red cell count and display this value. These results are available at the end of the counting period for the total cell count, no additional time or calculations being required.

We have tested these attachments for calculating the MCV and PCV and the purpose of this communication is to record our assessment of their performance.

\section{MATERIALS AND METHODS}

The attachments for measurement of the PCV and MCV were loaned by Coulter Electronics Ltd., together with a Coulter cell counter model F. The apparatus was installed by the manufacturers, calibrated and ready for use.

The red cell count was performed using a 1 in 50,000 dilution of the blood in phosphate buffered isotonic saline formulated as follows:

$$
\begin{aligned}
& \mathrm{NaCl} \ldots \ldots \ldots \ldots \ldots \ldots . \ldots . \ldots . \ldots \\
& \mathrm{KH}_{2} \mathbf{P O}_{4} \ldots \ldots \ldots \ldots \ldots \ldots \ldots \ldots \ldots+\mathbf{0} \mathbf{g} \\
& \mathrm{KCl} \ldots \ldots \ldots \ldots \ldots \ldots \ldots \ldots . \ldots \ldots \\
& \mathrm{Na}_{2} \mathrm{HPO}_{4} \mathbf{1 2}_{2} \mathrm{O} \ldots \ldots \ldots \ldots \ldots \ldots \ldots .1 \cdot 15 \mathrm{~g} \\
& \text { Di sod. versenate. . . . . . . . . . } 0 \cdot 2 \mathrm{~g} \\
& \text { Water to................. litre } \\
& \text { The } p \mathrm{H} \text { of this solution was } 6.8
\end{aligned}
$$

One hundred different samples of blood were counted from patients suffering from a variety of anaemias (megaloblastic, other macrocytic anaemias, haemolytic anaemias, microcytic, hypochromic, and symptomatic anaemias) as well as from patients with polycythaemia and normal persons. The MCV and PCV recorded by the machine were noted.

Received for publication 16 May, 1967 